\title{
The Influence of Multi-Sensory Stimulus to Parturition
}

\author{
$1^{\text {st }}$ Fania Nurul Khoirunnisa' \\ Universitas Muhammadiyah Kudus \\ Kudus, Indonesia \\ fanianurul@umkudus.ac.id \\ $4^{\text {th }}$ Alif Kiki \\ Universitas Muhammadiyah Kudus \\ Kudus, Indonesia \\ alifkiki@umkudus.ac.id
}

\author{
$2^{\text {nd }}$ Nor Asiyah \\ Universitas Muhammadiyah Kudus \\ Kudus, Indonesia \\ norasiyah@umkudus.ac.id
}

\author{
$3^{\text {rd }}$ Indah Risnawati \\ Universitas Muhammadiyah Kudus \\ Kudus, Indonesia \\ indahrisnawati@umkudus.ac.id
}

\begin{abstract}
Safe and satisfied parturition are influenced by anxiety suffered by mothers during maternity. Anxiety and pain during maternity cause stress responses. It increases catecholamine causing vasoconstriction which influences to womb contraction, pain, and parturition length. Multi-sensory stimuli are identified to be able in decreasing anxiety and facilitating maternal physiology. Multi-sensory stimuli are stimuli interventions on several human senses which are able to be responded by brain. It fosters influential perceptions to behaviors and emotions so it has indirect potency to parturition process. This research aims to analyze multi-sensory stimulus on maternity to parturition. This quasi-experimental research used nonequivalent control group design. The sample consisted of 60 people. The bivariable analysis design used Mann Whitney test and non-paired T-test. Two proportion test assisted by SPSS was used to find out the influence strength. The results showed that there was an influence of Multi-sensory stimulus to pain and length of parturition. The average of the pain during 6-8 aperture was on scale $7(\mathrm{SD}=1.73)$ meanwhile on control group it was on scale $8(\mathrm{SD}=1.7)$. The average of the parturition was 331.67 ( $\mathrm{SD}=97.001)$ while the control group was 400.00 minutes ( $\mathrm{SD}=163.87$ ). It is important for midwifery to explore various non-pharmacological effort to support parturition process and outcomes.
\end{abstract}

Keywords-Multi-sensory stimulus, parturition pain, parturition length

\section{INTRODUCTION}

Child and mother health level is a priority in Indonesian health development. High morbidity rate of mothers and babies becomes immediate problem to overcome. Annually, morbidity rate of women during parturition is 287.000 , or about $99 \%$ occurring in developing countries. Survey by Indonesian Health Democracy (SDKI) in 2012 showed morbidity rate of mothers reached 359 per 100.000 natality. It was the highest rate in ASEAN countries [1][2]. The government keeps its efforts to suppress the morbidity rate of mothers (AKI). One of them is by health service availability and standard maternal service quality improvement [2][3].

One of midwiferies' authorities is commencing normal parturition assistance [4]. Parturition is a valuable experience for each woman. Thus, midwifery as parturition assistance should struggle to create appropriate innovation to make maternity mothers could obtain impressive experience during parturition. Intervention to relieve pain, anxiety, and uncomfortably during maternity becomes main matter in providing modern service midwifery to such maternal mothers. A midwife has the responsibility to promote and use non-pharmacological technique to minimize anxiety and pain during maternity which influence to parturition process [5][2].

A midwife should ensure that mothers receive qualified prenatal service during maternity to obtain normal parturition process and should involve herself into decision making to what is best for maternal mothers and their babies as well as having choices concerning with places, action, and methods to commence parturition process [5][6][7].

Parturition experience is influenced by anxiety and pain suffered during maternity. Anxiety and exaggerate pain perception causes stress responses which influences on improvement of cortisone and adrenaline hormone. They influence to narrow blood vessels so the oxygen flow toward the womb decreases and causes functions of placenta. Weak womb contraction decreases placenta perfusion which causes lengthy time in parturition process [8][9].

Maternity pain is assumed as pressuring sensation and emotional experience dealing with actual or potential tissue damage as human immune system to reach toward any stimulus. There is a need of intervention given to avoid any further damage. Stimulation on human senses is a part of complementary medication to promote comfortability, selfcontrol and relaxation which make endorphins released.

Sense - stimulation intervention could be given visually, auditory, and palpably [10][11][12]. Human sense catch stimulus in the form of impulses, delivered through sensible nerves to central nerve in brain. Then, there is an appearance of object meaning in the individual called as perception. Then, brain delivers message through motoric nerve to command the muscles or certain glands to react, called as reflect arch. In maternity context, by the existence of such stimulus will influence on physical reaction and psychological of the mothers during maternity. It will influence to parturition process [10], [11].

A preliminary study evaluated the effects of Multisensory therapy as chronic pain management for disable 
persons with purpose to provide environment which could create relaxation and exhaustion digression. The finding showed that the therapy could significantly decrease the pain intensity and exhaustion $(\mathrm{P}<0.03)$ [11]. In this research, similar intervention was given to take the benefits and its effects for maternal mothers.

\section{METHODOLOGY}

The subjects consisted of maternal mothers. The sampling technique was consecutive sampling. The sample was grouped into two: intervention group and control group. In intervention group. The Multi-sensory stimulus were given by visual senses (using scenery and elements on the parturition place and unseen ergonomic position of the medical tools by the mothers), auditory (using classic instrumental music or Al-Qur'an murottal given to mothers based on their preferences), palpable sense (soft touch and massage). Meanwhile, the control group was given a typical intervention during parturition. Then, both groups were assessed in term of the maternal pain on $6-8 \mathrm{~cm}$ aperture and their parturition length.

The inclusive criteria of the maternal mothers consisted of primigravida, 37 - 42 week maternity, single maternity, head presentation, estimation of the fetus weight at about 2500 - 4000 gram, no contradiction on pervaginam maternity, no maternal complication, included into latent phase, planned and wanted maternity, under maternal supervision. The exclusive criteria were: women with maternal induction, straining distortion and power, more than 4 hour latent phase, premature membrane rupture, and mothers with visual and auditory disorders. The drop out criterion was referred maternal mothers.

The selection of pain scale data with Numeric Rating Scale sheet and maternal length data were done by calculating the duration of parturition in minutes which were recorded into partograph and observational sheet. Before being analyzed, its normality was tested by Saphiro - Wilk test. The data analysis to assess the difference of pain and length of the maternity of both groups was done by independent t-test or Mann Whitney test.

\section{RESULTS}

The subject characteristics of this research were age and maternal age. The age and maternal age are described in the table below.

\section{Table 1. The Characteristics of Women in Research Sample}

\begin{tabular}{lccc}
\hline \multicolumn{1}{c}{ Variable } & $\begin{array}{c}\text { Experimental } \\
\text { Group } \\
(\mathbf{n}=\mathbf{3 0})\end{array}$ & Control Group & P Value $^{\mathbf{a}}$ \\
\hline Age & $25(3.2)$ & $25(4.7)$ & \\
Gestational Age & $38(1.7)$ & $39(2.6)$ & 0.81 \\
\hline a Independent T-test & & &
\end{tabular}

Table 1 presents age characteristic data and maternal age of both groups. Based on statistics test by using non-paired T-test, the age and maternal age characteristics did not have any meaningful difference for both groups $(\mathrm{p}>0.05)$.
The comparative analysis of various investigated variables on both groups could be seen on the table below:

Table 2 Comparison of the Variables Research

\begin{tabular}{lccc}
\hline \multicolumn{1}{c}{ Variable } & $\begin{array}{c}\text { Experimental Group } \\
(\mathbf{n = 3 0 )}\end{array}$ & $\begin{array}{c}\text { Control Group } \\
(\mathbf{n = 3 0 )}\end{array}$ & P Value \\
\hline Pain intensity & $7(1.73)$ & $8(1.7)$ & $\mathbf{0 . 0 1}^{\mathbf{a}}$ \\
Mean (SD) & $6-9$ & $6-9$ & \\
Range & & & $\mathbf{0 , 0 5 4 ^ { b }}$ \\
$\begin{array}{l}\text { Duration of first } \\
\text { stage labor (minute) }\end{array}$ & $331,67(97,001)$ & $400,00(163,870)$ & \\
Mean (SD) & $180-540$ & $180-780$ & \\
Range & & & \\
$\begin{array}{l}\text { Duration of second } \\
\text { stage labor (minute) }\end{array}$ & $30,77(15,149)$ & $30,97(22,721)$ & \\
Mean (SD) & $8-60$ & $5-120$ & \\
Range & & & \\
\hline
\end{tabular}

${ }^{\text {a Mann-Whitney Test }}$

bIndependent T-test 
From table 2, it could be seen that maternal pain (7 vs 8 , $\mathrm{p}<0.05)$ and first time period $(331.67 \mathrm{vs} 400, \mathrm{p}<0.05)$ of both group had meaningful difference. Meanwhile, the second period of both groups did not have meaningful difference $(\mathrm{p}>0.05)$

\section{DISCUSSION}

Based on the age, there were 53 people $(88.3 \%)$ aged 20 35 year old and 7 people $(11.7 \%)$ aged $<20$ year old. Age is an indicator of personal maturity, organic, psychological, and various intellectual functions on life cycles of human development. In healthy behavioral context, chronological age with individual's ability in managing herself in an environment involves various understandings, exemplary, and judgments. Dealing with maternal age, the most typical weaknesses occurs on extended pregnancy, it could also influence parturition pain experience [12].

Maternal pain is caused by nociceptive caused from lower uterus segment mechanic distension and cervical aperture. Maternity triggers stress responses, on healthy level stress and healthy hormonal effect typically benefit the mothers and their babies during parturition. However, high anxiety and increasing pain perception result to stress responses which stimulate alpha-receptor on sympathetic neural system. It increases cortisone level and catecholamine which cause vasoconstriction and decreases blood flow carrying oxygen into womb. So, there is placenta perfusion digression and influences the womb contraction. Those factors could influence improvement and length of parturition [8], [13], [14].

Intervention to decrease maternal pain is Multi-sensory intervention. Multi-sensory stimulus is a pain management based on somatosensory stimulation (auditory, visual, and tactile/palpability). Adopting "Gate Control" theory, Multisensory stimulation was done through distraction effects of auditory stimulus and palpable effects as well as massage which are realization of the stimulus on large nerve fibers which could hinder the pain due to the "Close of the Gate"'[15][16].

The results showed that Multi-sensory stimulus intervention could relieve maternal pain $(\mathrm{p}<0.05)$ and it was correlated to length of first period parturition. Through the given stimulus on maternal women could cause inhibitory neuron in preventing projection neuron to send pain signals into the brain. Thus, the gate is closed and pain perception decreases.

The influential factors to length of first and second period of parturition were limitations in controlling several dependent variables, such as pain thresholds of the women, uterus contractility, and cervical conditions. The exaggerated activities of sympathetic nerves as influences of maternal pain and stress could influence uterus contraction, beta adrenergic stimulation to lower contractility of the uterus which causes to length of parturition. Maternal pain could take form into local pain accompanied by cramps and tearing sensation due to cervical distention and cervical, vaginal, or perineum tissue laceration. Pain with uterus contraction influences physiological mechanism of body system which always causes typical and thorough physiological stress responses. Many involuntary responses are natural methods to defend hemostasis. Besides that, pain could influence uterus contraction through secretion of catecholamine and cortisol which increased and influenced the duration of parturition. Noradrenaline was also proven causing lengthy parturition [17].

A similar study by Manesh et al about the benefit of snoezelen room, a relaxation room (combining the use of music, optical illusion, and aromatic oil) to parturition outcome. It was found that the room could decrease pain intensity of mothers $(P=0.01)$, parturition duration $(P=$ $0.042)$, and epsiotomy occurrence $(P=0.041)$. The received stimulus by human sense is processed in the forms of impulses which are delivered through sensing nerves into central nerve system in brain. It results to meaning about an object within an individual, called as perception. The brain, through motoric nerves, delivers the message and commands muscles or certain glands to react.

The visual mechanism of the given stimulus in this research resulted to endorphins hormone production through Biophilia. It is an effort to increase positive affiliation with the nature and living environment, to connect the environment with individuals directly and indirectly by using interior elements usages and ornaments in artificial parturition place. Various facts collected from natural element usages in health domain, statistically, are proven effective to quickly cure, to treat shorter, and to decrease stress hormone activation, plus to support oxytocin hormone secretion. This hormone, cooperated by prostaglandins, ensures improvement of frequency, length, and strength of myometrium contraction [18] [19].

The next series of intervention were from classical music instruments and murottal Al-Qur'an which worked by decreasing stimuli concentration on the women. By adapting Gate Control theory which explains how a stimulus could decrease pain during maternity, the pain impulse which goes to spinal medulla is inhibited by stimulation the auditory sense in the form of music or Al-Qur'an verse voice. The previous study also mentioned that listening to music could have greater relaxation effect and shorter parturition time $(\mathrm{p}<0.05)$. Furthermore, the voices of Al-Qur'an verses are responded by brain. They stimulate pituitary gland to release endorphins to control the pain [20][19]. Meanwhile, the tactile effects and massage during parturition process were used as manual process done for systemic purposes: decreasing pain severity and muscular contraction relaxation during parturition [21].

Basically, any helper during parturition could provide various intervention or pain management to produce stimulus which could be responded by human sensing system so it could foster perception which influence on physics, emotion, and indirect potency to parturition process such as supporting contraction. Adequate uterus contraction influences length of parturition to make it normal.

The limitation of this research was the sample size. The effects on multipara women were not also investigated. The researchers had obtained consent of the respondents and guaranteed their identities and the taken data. 


\section{CONCLUSION}

Multi-sensory stimulus interventions are able to reduce labor pain $(\mathrm{p}<0.05)$ and correlate with duration of labor when 1 . Interventions given adapt the gate control theory that explains how a stimulus can reduce pain in labor, the journey of pain impulses to the spinal cord is hampered due to stimulation. It is important for birth attendants to modify various non-pharmacological interventions in the labor process so that the mother feels comfortable and labor is normal.

\section{ACKNOWLEDGMENT}

Thanks to the research subjects who voluntarily participated in this research as well as other parties and Universitas Muhammadiyah Kudus

\section{REFERENCES}

[1] B. Kependudukan and B. Nasional, "Survei Demografi dan Kesehatan Indonesia," 2013

[2] I. Indrianingrum, I. Tristanti, and A. Info, "Jurnal Kesehatan Masyarakat," vol. 15, no. 1, pp. 44-52, 2019.

[3] E. Of, V. Coconut, V. Olive, O. I. L. On, and P. Laceration, "Jurnal Kesehatan Masyarakat EFFECTIVENESS OF VIRGIN COCONUT OIL AND VIRGIN OLIVE OIL ON," vol. 14, no. 3, pp. 396-403, 2018.

[4] P. Menteri et al., "BERITA NEGARA," no. 954, 2017.

[5] P. Manizheh and P. Leila, "Perceived environmental stressors and pain perception during labor among primiparous and multiparous women.," J. Reprod. Infertil., vol. 10, no. 3, pp. 217-23, 2009.

[6] "1 Foureur MJ, Davis D, Fenwick J, Leap N, Iedema R, Forbes I, Homer CSE. (2010) The relationship between birth unit design and safe, satisfying birth: Developing a hypothetical model," pp. 520 $525,2010$.

[7] L. Page, "Creating a better birth environment," Br. J. Midwifery, vol 11 , no. 12, pp. 714-714, 2003

[8] K. Yesilcicek Calik and N. Komurcu, "Effects of SP6 Acupuncture Point Stimulation on Labor Pain and Duration of Labor," Iran. Red Crescent Med. J., vol. 16, no. 10, 2014.

[9] M. Dolatian, A. Hasanpour, S. Montazeri, R. Heshmat, and H. A. Majd, "The Effect of Reflexology on Pain Intensity and Duration of Labor on Primiparas," vol. 13, no. 7, pp. 475-479, 2011.

[10] M. F. Yam, Y. Chun, L. Id, and C. S. Tan, "General Pathways of Pain Sensation and the Major Neurotransmitters Involved in Pain Regulation," 2018

[11] M. J. Manesh, M. Kalati, and F. Hosseini, "Snoezelen Room and Childbirth Outcome: A Randomized Clinical Trial," vol. 17, no. 5, 2015.

[12] E. Fania, N. Khoirunnisa, D. Andriani, and S. M. Kudus, "K ARAKTERISTIK M ATERNAL D AN R ESPON T ERHADAP N YERI," vol. 1, no. 2, pp. 93-99, 2017.

[13] M. I. van den Heuvel, M. A. Johannes, J. Henrichs, and B. R. H. Van den Bergh, "Maternal mindfulness during pregnancy and infant socioemotional development and temperament: The mediating role of maternal anxiety," Early Hum. Dev., vol. 91, no. 2, pp. 103-108, 2015 .

[14] A. Einion, Hormonal physiology of childbearing: Evidence and implications for women, babies and maternity care, vol. 20, no. 4. 2017.

[15] M. Bahrudin, "Patofisiologi Nyeri (Pain)," Saintika Med., vol. 13, no. 1, p. 7, 2018

[16] 2013 John R. Giudicessi, BA.Michael J.Ackerman., “基因的改变NIH Public Access," Bone, vol. 23, no. 1, pp. 1-7, 2008 .

[17] Y. Sano, T. Doi, S. Kikuchi, K. Kawai, and M. Tanaka, "Correlations between stress hormone levels in umbilical cord blood and duration of delivery," J. Pak. Med. Assoc., vol. 65, no. 7, pp. 782-784, 2015.

[18] P. Issue, "The emotional and hormonal pathways of labour and birth: integrating mind, body and behaviour," pp. 15-23.

[19] M. Schweitzer, L. Gilpin, and S. Frampton, "Healing spaces:
Elements of environmental design that make an impact on health," $J$. Altern. Complement. Med., vol. 10, no. SUPPL. 1, 2004.

[20] N. S. Oktavia, S. Gandamiharja, and I. B. Akbar, "Perbandingan Efek Musik Klasik Mozart dan Musik Tradisional Gamelan Jawa terhadap Pengurangan Nyeri Persalinan Kala I Fase Aktif pada Nulipara," Maj. Kedokt. Bandung, vol. 45, no. 4, pp. 218-225, 2013.

[21] N. K. Karami, A. Safarzadeh, and N. Fathizadeh, "Effect of Massage Therapy on Severity of Pain and Outcome of Labor in Primipara," Iran. J. Nurs. Midwifery Res., vol. 12, no. 1, pp. 6-9, 2007. 